\title{
Effect of sulfur fertilization on the physical and chemical properties of crambe (Crambe abyssinica Hochst ex R.E. Fries) seeds
}

\author{
Ewa Ropelewska* and Krzysztof J. Jankowski \\ Department of Agrotechnology, Agricultural Production Management and Agribusiness, Faculty of Environmental Management and \\ Agriculture, University of Warmia and Mazury in Olsztyn, M. Oczapowskiego 8, 10-719 Olsztyn, Poland
}

Received 7 November 2019 - Accepted 2 March 2020

\begin{abstract}
Crambe seeds have numerous industrial applications. Crambe seed oil contains mostly monounsaturated fatty acids. Seeds contain crude protein, amino acid, glucosinolates. They are used in human and animal nutrition. The aim of this study was to determine the physical and chemical properties of crambe seeds subjected to fertilization at $0,15,30 \mathrm{~kg} \mathrm{~S} h a^{-1}$. Thousand seed weight ranged from $6.93 \mathrm{~g}(0 \mathrm{~S})$ to $8.04 \mathrm{~g}(30 \mathrm{~S})$. All results were statistically significantly different. Length $(L)$ of seeds ranged from $2.20 \mathrm{~mm}(0 \mathrm{~S}, 15 \mathrm{~S})$ to $2.24 \mathrm{~mm}(30 \mathrm{~S})$, width $(S)$ ranged from $1.90 \mathrm{~mm}(0 \mathrm{~S})$ to $1.95 \mathrm{~mm}(30 \mathrm{~S})$, surface area $(F)$ ranged from $3.53 \mathrm{~mm}^{2}(0 \mathrm{~S})$ to $3.67 \mathrm{~mm}^{2}(30 \mathrm{~S})$. All samples $(0 \mathrm{~S}, 15 \mathrm{~S}, 30 \mathrm{~S})$ formed one homogenous group for the values of $L, S, F$. Crude fat content was $349.8 \mathrm{~g} \mathrm{~kg}^{-1} \mathrm{DM}(0 \mathrm{~S})$ to $377.9 \mathrm{~g} \mathrm{~kg}^{-1} \mathrm{DM}(30 \mathrm{~S})$ and crude protein content was $241.0 \mathrm{~g} \mathrm{~kg}^{-1} \mathrm{DM}(0 \mathrm{~S})$ to $250.3 \mathrm{~g} \mathrm{~kg}^{-1} \mathrm{DM}(30 \mathrm{~S})$. The results for each sample were statistically significantly different. The results can be used in practice to determine the dose of sulfur fertilizer. Fertilization caused changes in 1000 seed weight of crambe. Additionally, selected linear dimensions and shape factors of crambe seeds were affected by fertilizer. Sulfur fertilization caused changes in the crude fat and crude protein content of crambe seeds.
\end{abstract}

Keywords: crambe seeds / sulfur fertilization / physical properties / chemical properties

\begin{abstract}
Résumé - Effet de la fertilisation au soufre sur les propriétés physiques et chimiques des graines de crambe (Crambe abyssinica Hochst ex R.E. Fries). Les graines de crambe ont de nombreuses applications industrielles. L'huile de graines de crambe contient principalement des acides gras monoinsaturés. Les graines contiennent des protéines brutes, des acides aminés, des glucosinolates. Elles sont utilisées dans l'alimentation humaine et animale. L'objectif de cette étude était de déterminer les propriétés physiques et chimiques des graines de crambe soumises à une fertilisation à $0,15,30 \mathrm{~kg} \mathrm{~S}^{-1}$. Le poids de 1000 grains variait de $6,93 \mathrm{~g}(0 \mathrm{~S})$ à $8,04 \mathrm{~g}(30 \mathrm{~S})$. Tous les résultats étaient statistiquement différents. La longueur $(L)$ des graines variait de $2,20 \mathrm{~mm}(0 \mathrm{~S}, 15 \mathrm{~S})$ à $2,24 \mathrm{~mm}(30 \mathrm{~S})$, la largeur $(S)$ de $1,90 \mathrm{~mm}(0 \mathrm{~S})$ à $1,95 \mathrm{~mm}(30 \mathrm{~S})$, la surface $(F)$ de $3,53 \mathrm{~mm}^{2}(0 \mathrm{~S})$ à $3,67 \mathrm{~mm}^{2}(30 \mathrm{~S})$. Tous les échantillons $(0 \mathrm{~S}, 15 \mathrm{~S}, 30 \mathrm{~S})$ formaient un groupe homogène pour les valeurs de $L, S, F$. La teneur brute en lipides variait de $349,8 \mathrm{~g} \mathrm{~kg}^{-1}(0 \mathrm{~S})$ à $377,9 \mathrm{~g} \mathrm{~kg}^{-1}$

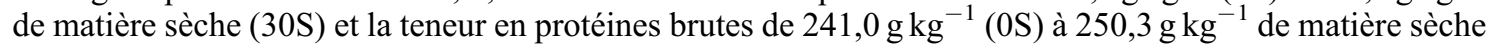
(30S). Les résultats pour chaque échantillon étaient statistiquement différents. Les résultats peuvent être utilisés en pratique pour déterminer la dose d'engrais soufré. La fertilisation a provoqué des changements dans le poids de 1000 grains de crambe. De plus, certaines dimensions linéaires et certains facteurs de forme des graines de crambe ont été affectés par l'engrais. La fertilisation au soufre a provoqué des changements dans la teneur en graisse brute et en protéines brutes des graines de crambe.
\end{abstract}

Mots clés : graines de crambe / fertilisation au soufre / propriétés physiques / propriétés chimiques

\footnotetext{
*Correspondence: ewa.ropelewska@uwm.edu.pl
} 


\section{Introduction}

Crambe (Crambe abyssinica Hochst ex R.E. Fries) is native to the Mediterranean region and the highlands of eastern Africa. The species is also cultivated in the USA, Canada, several European countries (Poland, Sweden, Italy), Pakistan, India and China (Fontana et al., 1998, Wang et al., 2000). Crambe is grown as a spring crop in the temperate zone and as a winter crop in the Mediterranean region. The species is characterized by a short growing season (90-100 days), drought tolerance, disease- and pest-resistance (Machado et al., 2007). Due to its high plasticity and environmental adaptability, crambe can be grown in regions with precipitation levels of 350 to $1200 \mathrm{~mm} \mathrm{y}^{-1}$, mean annual air temperature of 5-6 to $26^{\circ} \mathrm{C}$, and soil pH of 5 to 7.8 (Falasca et al., 2010).

Average crambe yields range from 0.6-1.6 (Budzyński and Jankowski, 1999; dos Santos et al., 2013; Rogério et al., 2013) to $2.5 \mathrm{Mg} \mathrm{ha}^{-1}$ (Falasca et al., 2010). The oil content of crambe seeds is $300-430 \mathrm{~g} \mathrm{~kg}^{-1} \mathrm{DM}$ (Zadernowski et al., 1999; Machado et al., 2007; Falasca et al., 2010; Lalas et al., 2012). According to Temple-Heald (2004), the yield potential of new crambe varieties (measured as bio-oil yield) is comparable with that of spring oilseed rape. Crambe seed oil contains mostly monounsaturated fatty acids (75-80\%), with predominance (50-60\%) of erucic acid (Zadernowski et al., 1999) which has numerous industrial applications. It can be used as an industrial lubricant, a corrosion inhibitor, an ingredient in the manufacture of synthetic rubber, plastic films, plasticizers, nylon, adhesives and electrical isolation (VargasLopez et al., 1999). Erucamide, a substance yielded from crambe seed oil, is used in the cosmetic industry and as a slip agent critical to the manufacture and use of polyolefin films (Vargas-Lopez et al., 1999; Falasca et al., 2010). The use of crambe as biofuel has been investigated in Argentina (Falasca et al., 2010) and Brazil (Rosa et al., 2014). Crambe meal is a high-protein additive for livestock. It contains approximately $250-350 \mathrm{~g} \mathrm{~kg}^{-1} \mathrm{DM}$ of crude protein when siliques are included, and protein content can be increased to 460$580 \mathrm{~g} \mathrm{~kg}^{-1} \mathrm{DM}$ by removing the siliques (Falasca et al., 2010). Due to its desirable amino acid composition, crambe meal is fed to cattle e.g. in the USA (Falasca et al., 2010). However, crambe seeds contain also nutritionally undesirable biologically active compounds-glucosinolates (GLS). Unmodified and hydrolyzed GLS can compromise the quality of crambe meal and cake, thus limiting their use in monograstric animal nutrition (Lazzeri et al., 1994).

The aim of this study was to compare selected physical and chemical properties of crambe seeds subjected to sulfur fertilization at $0,15,30 \mathrm{~kg} \mathrm{Sha}^{-1}$. The values of 1000 seed weight, bulk density, true density, porosity, length, width, surface area, object boundary specific perimeter, maximum Martin radius, folding factor, mean thickness factor, compactness, roundness, Blair-Bliss coefficient, crude fat content and crude protein content of seeds were determined. The studies of seed properties can be important for practical applications in industry. The results can be practically used to determine the desired dose of sulfur fertilizer, which provides seeds with the best characteristics. It can be important for harvesting. Improvement of seeds properties can affect their further processing. Therefore, these studies are important and have practical significance.

\section{Materials and methods}

Crambe seeds were produced in 2018, in a small-scale field experiment conducted at the Agricultural Experiment Station in Bałcyny $\left(\mathrm{N}=53^{\circ} 35^{\prime} 49^{\prime \prime} ; \mathrm{E}=19^{\circ} 51^{\prime} 20.3^{\prime \prime}\right)$ owned by the University of the Warmia and Mazury in Olsztyn. Before sowing, different rates of sulfur $\left(\mathrm{kg} \mathrm{ha}^{-1}\right): 0,15,30$ were applied as potassium sulfate.

The experiment had a randomized complete block design with three replications. Plot size was $15 \mathrm{~m}^{2}(10 \times 1.5 \mathrm{~m})$. Presowing soil tillage treatments included skimming, winter plowing and mechanical loosening. Seeds of crambe cv. "Borowski" were sown at the beginning of April with a plot seeder at a density of 200 pure live seeds $\mathrm{m}^{-2}$, spacing of $19 \mathrm{~cm}$, to a depth of $1.5-2.0 \mathrm{~cm}$. Immediately before sowing, $80 \mathrm{~kg} \mathrm{~N}$ $\mathrm{ha}^{-1}$ was applied as ammonium nitrate, $40 \mathrm{~kg} \mathrm{P}_{2} \mathrm{O}_{5} \mathrm{ha}^{-1}$ was applied as enriched superphosphate, and $100 \mathrm{~kg} \mathrm{ha}^{-1} \mathrm{~K}_{2} \mathrm{O}$ was applied as potassium sulfate and potash salt. At the beginning of inflorescence emergence of crambe, the second dose of nitrogen $\left(40 \mathrm{~kg} \mathrm{ha}^{-1}\right)$ was applied as ammonium nitrate. Butisan $400 \mathrm{SC}$ was applied at $2.5 \mathrm{dm}^{3} \mathrm{ha}^{-1}$ (1000 $\mathrm{g} \mathrm{ha}^{-1}$ metazachlor) directly after sowing. Crambe was harvested at physiological maturity using a small-plot harvester.

Thousand dehulled seed weight [g] was determined according to the International Rules for Seed Testing (ISTA, 2013). Bulk density $\left[\mathrm{g} \mathrm{cm}^{-3}\right]$ was measured based on Standard EN ISO 7971-3:2009 with the use of a $100 \mathrm{~cm}^{3}$ graduated cylinder. True density $\left[\mathrm{g} \mathrm{cm}^{-3}\right]$ was determined according to Standard PN-EN 1097-6:2013 using a $100 \mathrm{~cm}^{3}$ glass pycnometer and a water-insoluble liquid. True density $\left[\mathrm{g} \mathrm{cm}^{-3}\right]$ was calculated from the equation (1):

$$
\rho_{t}=\frac{m_{0}}{m_{0}-m_{1}} * p_{c}
$$

where: $\rho_{t}$ : true density; $m_{0}$ : dehulled seed mass in air; $m_{1}$ : dehulled seed mass in liquid; $\rho_{c}$ : liquid density at a known temperature.

Porosity [\%] was calculated based on the formula (2):

$$
\varepsilon=\frac{\rho_{t}-\rho_{b}}{\rho_{t}} * 100[\%]
$$

where: $\varepsilon$ is porosity, $\rho_{t}$ is true density, $\rho_{b}$ is bulk density.

All measurements were carried out in five replicates.

The geometric parameters of crambe dehulled seeds were determined by computer image analysis with the use of a Canon flatbed scanner and SilverFast scanning software (LaserSoft Imaging, Inc., USA). Images of crambe dehulled seeds were obtained at a resolution of 800 dpi and were saved in TIFF format. The images were analyzed using MaZda software (Łódź University of Technology, Institute of Electronics, Poland) (Szczypiński et al., 2009). Geometric parameters were determined for each seed.

Dehulled seed samples were scanned in the NIR Systems 6500 monochromator (FOSS NIR Systems Inc., USA) equipped with a reflectance module. Intact seeds (approx. $5 \mathrm{~g}$ ) were placed in a standard ring cup and scanned. The results were predicted by partial least squares (PLS) calibrations established for total protein (reference data from the Kjeldahl method) and crude fat (Soxhlet extraction method). 
Table 1. Properties of crambe seeds subjected to sulfur fertilization.

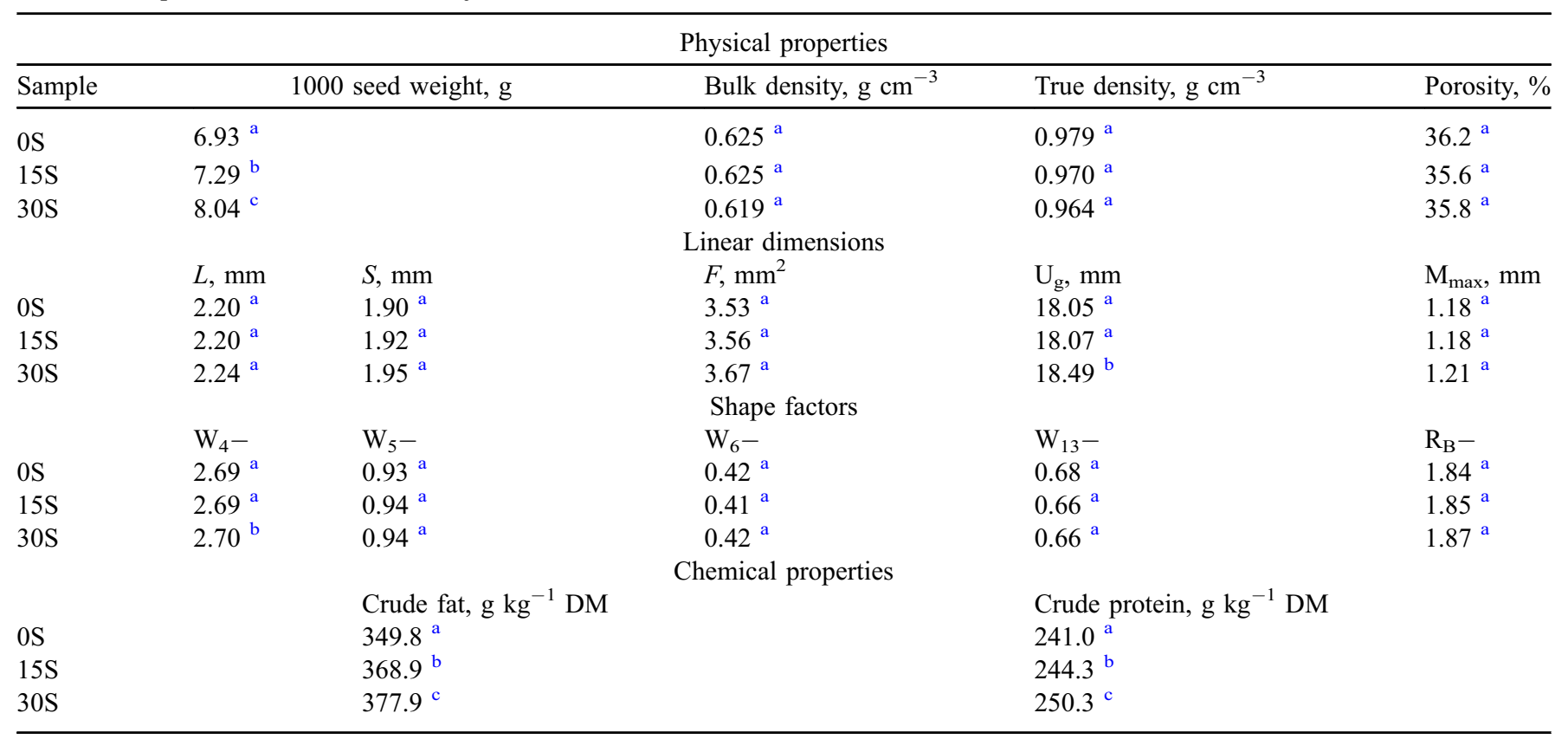

a denote homogeneous groups, $P \leq 0.05$.

${ }^{\mathrm{b}}$ denote homogeneous groups, $P \leq 0.05$.

${ }^{\mathrm{c}}$ denote homogeneous groups, $P \leq 0.05$.

$L$ : length; $S$ : width; $F$ : surface area; $\mathrm{U}_{\mathrm{g}}$ : object boundary specific perimeter; $\mathrm{M}_{\max }$ : maximum Martin radius; $\mathrm{W}_{4}-:$ folding factor; $\mathrm{W}_{5}-:$ mean thickness factor; $\mathrm{W}_{6}-$ : compactness; $\mathrm{W}_{13}-$ : roundness; $\mathrm{R}_{\mathrm{B}}-$ : Blair-Bliss coefficient.

The results were analyzed statistically using Statistica 12.0 (StatSoft Inc., Tulsa, USA) software. The differences in the values of the examined physical, geometric and chemical parameters of seeds were determined at a significance level of $P \leq 0.05$. The homogeneity of variance was checked and the normality of distribution was verified. Normally and nonnormally distributed variables were analyzed by the NewmanKeuls parametric test and the Kruskal-Wallis non-parametric test, respectively.

\section{Results and discussion}

\subsection{Physical properties of crambe seeds}

The mean values of 1000 seed weight, bulk and true densities and porosity of crambe are presented in Table 1 . The 1000 seed weight was equal to from 6.93 to $8.04 \mathrm{~g}$. The highest result was determined for seeds fertilized with $30 \mathrm{~kg} \mathrm{Sha}^{-1}$ and was significantly higher than 1000 seed weight of seeds fertilized with $15 \mathrm{~kg} \mathrm{Sha}^{-1}$ and seeds without sulfur fertilization $\left(0 \mathrm{~kg} \mathrm{Sha}^{-1}\right)$. Sulfur fertilization did not statistically significantly affect other tested physical properties. For bulk density, true density and porosity all samples formed one homogenous group. Crambe seeds had bulk density of $0.619 \mathrm{~g} \mathrm{~cm}^{-3}(30 \mathrm{~S})$ to $0.625 \mathrm{~g} \mathrm{~cm}^{-3}(0 \mathrm{~S}, 15 \mathrm{~S})$, true density of $0.964 \mathrm{~g} \mathrm{~cm}^{-3}(30 \mathrm{~S})$ to $0.979 \mathrm{~g} \mathrm{~cm}^{-3}(0 \mathrm{~S})$, and porosity of $35.6(15 \mathrm{~S})$ to $36.2 \%(0 \mathrm{~S})$.

The values of 1000 seed weight of crambe, determined in this study, are similar to those found in the available literature. Reuber et al. (2001) reported a value of $6.2 \mathrm{~g}$. In a study by
Zanetti et al. (2013), the 1000 seed weight of crambe (Crambe abyssinica) reached 6.00-7.50 g, whereas Tansi et al. (2017) reported that the 1000 seed weight of crambe ranged from 6.00 to $9.98 \mathrm{~g}$ in Crambe orientalis up to $17.80 \mathrm{~g}$ in Crambe tataria. Comparing with the available literature data, the densities of crambe seeds determined in own studies are lower than the values obtained for other oilseed species, e.g. rapeseed whose bulk density reached $0.664-0.675 \mathrm{~g} \mathrm{~cm}^{-3}$, and true density ranged from $1.029-1.074 \mathrm{~g} \mathrm{~cm}^{-3}$ (Ropelewska et al., 2017) or mustard whose bulk density was determined at $0.729-0.755 \mathrm{~g} \mathrm{~cm}^{-3}$ and true density at $1.169-1.203 \mathrm{~g} \mathrm{~cm}^{-3}$ (Ropelewska et al., 2018).

\subsection{Geometric properties of crambe seeds}

The mean values of selected linear dimensions and shape factors of crambe seeds are presented in Table 1. Sulfur fertilization affected the length $(L)$, width $(S)$, surface area $(F)$, object boundary specific perimeter $\left(U_{g}\right)$ and maximum Martin radius $\left(M_{\text {max }}\right)$ of seeds. The values of $L$ parameter of crambe seeds were equal to $2.20-2.24 \mathrm{~mm}$. The seeds were characterized by a width of 1.90 to $1.95 \mathrm{~mm}$ and surface area from 3.53 to $3.67 \mathrm{~mm}^{2}$. The other values were as follows: $U_{g}$ : $18.05-18.49 \mathrm{~mm}$, and $M_{\max }: 1.18-1.21 \mathrm{~mm}$. The highest values of length, width, surface area, object boundary specific perimeter and maximum Martin radius were observed in seeds fertilized with the highest sulfur rate $\left(30 \mathrm{~kg} \mathrm{Sha}^{-1}\right)$, and the lowest values of the above parameters were noted in unfertilized seeds $\left(0 \mathrm{~kg} \mathrm{Sha}^{-1}\right)$. In crambe seeds, all samples 
(0S, 15S, 30S) formed one homogenous group with respect to the values of $L, S, F$ and $M_{\max }$ due to considerable variation in seed size. Two groups were formed based on the values of $U_{g}$ : one group comprised samples fertilized with 0 and $15 \mathrm{~kg} \mathrm{~S}$ $\mathrm{ha}^{-1}$ and the other group consisted of the sample fertilized with $30 \mathrm{~kg} \mathrm{Sha}^{-1}$. Values of shape factors of crambe seeds were in the ranges: $W_{4}-:$ 2.69-2.70, $W_{5}-: 0.93-0.94, W_{6}-: 0.41-$ $0.42, W_{13}-: 0.66-0.68$, and $R_{B}-: 1.84-1.87$. Based on the values of $\mathrm{W}_{4}$, the $0 \mathrm{~S}$ and $15 \mathrm{~S}$ samples of crambe seeds formed one homogeneous group, and the $30 \mathrm{~S}$ sample formed another group with the highest value. With respect to the values of the remaining parameters, all samples of crambe seeds formed one group. In other studies, the diameter of crambe (Crambe abyssinica) seeds was $2.7 \mathrm{~mm}$ (Reuber et al., 2001) and 0.8$2.55 \mathrm{~mm}$ (Lalas et al., 2012). Tansi et al. (2017) reported seed length of $1.26-2.21 \mathrm{~mm}$ and seed width of $1.18-2.00 \mathrm{~mm}$ in Crambe orientalis, and seed length of $2.02-2.88 \mathrm{~mm}$ and seed width of $1.86-2.83 \mathrm{~mm}$ in Crambe tataria. These values are similar to those obtained in own studies.

\subsection{Chemical properties of crambe seeds}

The values of the crude fat content and crude protein content of seeds are presented in Table 1. Seeds supplied with the highest rate of sulfur $\left(30 \mathrm{~kg} \mathrm{Sha}^{-1}\right)$ had the highest crude protein content $\left(250.3 \mathrm{~g} \mathrm{~kg}^{-1} \mathrm{DM}\right)$, whereas unfertilized seeds had the lowest crude protein content $\left(241.0 \mathrm{~g} \mathrm{~kg}^{-1} \mathrm{DM}\right)$. The results for each sample were statistically significantly different. Crude fat content was highest $\left(377.9 \mathrm{~g} \mathrm{~kg}^{-1} \mathrm{DM}\right)$ in the sample fertilized with the highest rate of sulfur, and lowest $\left(349.8 \mathrm{~g} \mathrm{~kg}^{-1} \mathrm{DM}\right)$ in the unfertilized sample. All results of crude fat content were statistically significantly different.

\section{Conclusions}

This study concludes that sulfur fertilization contributed to a significant increase in the 1000 seed weight of crambe. Sulfur fertilization had no significant effect on the bulk density, true density or porosity of crambe seeds. Due to considerable variation in the size and shape of crambe seeds, only the sample fertilized with $30 \mathrm{~kg} \mathrm{Sha}^{-1}$ was characterized by significantly higher values of object boundary specific perimeter and folding factor, compared with the remaining samples. Sulfur fertilization caused a significant increase in the crude fat and crude protein content of crambe seeds.

Conflict of interest. The authors declare that they have no conflicts of interest in relation to this article.

Acknowledgements. The results presented in this paper were obtained as part of a comprehensive study financed by the University of Warmia and Mazury in Olsztyn (Grant no. 20.610.020-110). Project financially supported by Minister of Science and Higher Education in the range of the program entitled "Regional Initiative of Excellence" for the years 20192022, project No. 010/RID/2018/19, amount of funding 12.000.000 PLN.

\section{References}

Budzyński WS, Jankowski KJ. 1999. Effect of sulphur, magnesium and nitrogen fertilization on yielding and yield components of spring false flax and crambe. Zesz Probl Post Nauk Roln 468: 311-321.

dos Santos JI, da Silva TRB, Rogério F, Santos RF, Secco D. 2013. Yield response in crambe to potassium fertilizer. Ind Crops Prod 43: 297-300.

Falasca SL, Flores N, Lamas MC, Carballo SM, Anschau A. 2010. Crambe abyssinica: An almost unknown crop with a promissory future to produce biodiesel in Argentina. Int J Hydrog Energy 35: 5808-5812.

Fontana F, Lazzeri L, Malaguti L, Galletti S. 1998. Agronomic characterization of some Crambe abyssinica genotypes in a locality of the Po Valley. Eur J Agron 9: 117-126.

International Seed Testing Association (ISTA). 2013. International rules for seed testing.

Lalas S, Gortzi O, Athanasiadis V, Dourtoglou E, Dourtoglou V. 2012. Full characterisation of Crambe abyssinica Hochst. seed oil. J Am Oil Chem Soc 89: 2253-2258.

Lazzeri L, Leoni O, Conte LS, Palmieri S. 1994. Some technological characteristics and potential uses of Crambe abyssinica products. Ind Crop Prod 3: 103-112.

Machado MF, Brasil AN, Oliveira LS, Nunes DL. 2007. Estudo do crambe (Crambe abyssinica) como fonte de óleo para produção de biodiesel. Itaúna/MG-UFMG.

Reuber MA, Johnson LA, Watkins LR. 2001. Dehulling crambe seed for improved oil extraction and meal quality. $\mathrm{J} \mathrm{Am} \mathrm{Oil} \mathrm{Chem} \mathrm{Soc}$ 78(6): 661-664.

Rogério F, da Silva TRB, dos Santos JI, Poletine JP. 2013. Phosphorus fertilization influences grain yield and oil content in crambe. Ind Crops Prod 41: 266-268.

Ropelewska E, Zapotoczny P, Budzyński WS, Jankowski KJ. 2017. Discriminating power of selected physical properties of seeds of various rapeseed (Brassica napus L.) cultivars. J Cereal Sci 73: 62-67.

Ropelewska E, Jankowski KJ, Zapotoczny P, Bogucka B. 2018. Thermophysical and chemical properties of seeds of traditional and double low cultivars of white mustard. Zemdirbyste-Agric 105(3): 257-264.

Rosa HA, Wazilewski WT, Secco D, Chaves LI, Veloso G, Souza SNM. 2014. Biodiesel produced from crambe oil in Brazil-A study of performance and emissions in a diesel cycle engine generator. Renew Sustain Energy Rev 38: 651-655.

Szczypiński PM, Strzelecki M, Materka A, Klepaczko A. 2009. MaZda-A software package for image texture analysis. Comp Meth Prog Bio 94(1): 66-76.

Tansi S, Karaman S, Tonçer O, Çömlekçioğlu N. 2017. Potential, cultivation and quality of some crambe sp. in Southern Turkey. Cercetari Agron Moldova 50(1): 89-100.

Temple-Heald C. 2004. High erucic oil: Its production and uses. In: Gunstone FD, ed. Rapeseed and canola oil: Productions, properties and uses. Oxford: Blackwell Publishing, CRC Press, pp. 111-129.

Vargas-Lopez JM, Wiesenborn D, Tostenson K, Cihacek L. 1999. Processing of crambe for oil and isolation of erucic acid. $\mathrm{J} \mathrm{Am}$ Oils Chem Soc 76: 801-809.

Wang YP, Tang JS, Chu CQ, Tian J. 2000. A preliminary study on the introduction and cultivation of Crambe abyssinica in China, an oil plant for industrial uses. Ind Crops Prod 12: 47-52.

Zadernowski R, Budzyński W, Nowak-Polakowska H, Rashed AA, Jankowski K. 1999. Effect of fertilisation on the composition of 
lipids from false flax (Camelina sativa L. Cr.) and crambe (Crambe abissinica Hochst.). Rosliny-Oleiste/Oils Crops 20: 503-510.
Zanetti F, Monti A, Berti MT. 2013. Challenges and opportunities for new industrial oilseed crops in EU-27: A review. Ind Crops Prod 50: $580-595$.

Cite this article as: Ropelewska E, Jankowski KJ. 2020. Effect of sulfur fertilization on the physical and chemical properties of crambe (Crambe abyssinica Hochst ex R.E. Fries) seeds. OCL 27: 18. 